\title{
A Comparative HPLC Quantification of Vatsanabha (Aconitum ferox Wall ex Seringe.) Root Processed in Cow's Urine and Cow's Milk
}

\author{
Research Article
}

\section{Gajanan Diliprao Chatuphale1*, Sonali Chalakh², Meghsham Anjankar³}

\author{
1. PhD Scholar, 2. HOD, Department of Agadtantra, 3. PhD Scholar, \\ Mahatma Gandhi Ayurved College, Hospital \& Research Centre, \\ Datta Meghe Institute of Medical Science, Salod (H), Wardha.
}

\begin{abstract}
Vatsanabh mula (Aconitum ferox Wall ex Seringe root); is toxic due to its chief active principle an alkaloid named as Aconitine. According to Ayurveda and modern science; it is included in one of the most poisonous plants known till today to mankind. Despite it is used widely in Ayurvedic treatment in various diseases. So its use in medicinal preparation should be done only after proper processing termed as Shodhan (purification) procedures. These processings are done in specific media. Shodhan procedures enhance therapeutic properties of Vatsanabha, reduce its toxicity \& convert it into medicine. In Ayurvedic literature, media like Gomutra (Cow's urine), Godugdha (Cow's milk) and Ajadugdha (Goat's milk) has been mentioned for Shodhan procedures of Vatsanabha. This study focuses on effect of two Shodhan procedures of Vatsanabha Mula by using Gomutra (cow's urine) and Godugdha (cow's milk) on HPLC quantification of Aconitine while the raw roots were taken as control. Changes in HPLC chromatogram confirm the effect of Shodhan procedure on Vatsanabha. In HPLC analysis, peaks were observed at retention time 30.1. Areas under the curve were less in the samples after purification with cow's urine compared to purification with cow's milk, indicating denaturation of some component after purification. Hence, Vatsanabha mula purified by Gomutra (cow's urine) may be regarded as better method of purification as far as toxic alkaloids are concerned.
\end{abstract}

Key Words: Vatsanabha Mula, Alkaloids, Shodhan, HPLC, Aconitine, Visha.

\section{Introduction}

Aconite (Vatsanabha) is mentioned as Kanda Visha (Tuber Poison) and having four types as mentioned in Sushrutsamhita centuries back(1). The most common aconite-based medicinal plant Vatsanabha (Aconitum ferox Wall ex Seringe.) is a therapeutically potent plant in Ayurveda and its roots are being used extensively in different classical formulations (2). The plant is mentioned under the Visha group (Highly poisonous inanimate or static poisons) in texts of Ayurveda Rasashastra(3). Shodhan procedures of Vatsanabha root which were supposed to reduce the toxic effects of the drug without compromising its pharmacological properties rather enhancing medicinal value was thus described in many ancient texts of Ayurveda Rasashastra(4). It is cited in the treatises of Ayurveda, the Visha (poison) becomes

\section{* Corresponding Author:}

\section{Gajanan Diliprao Chatuphale}

PhD Scholar, Mahatma Gandhi Ayurved College,

Hospital \& Research Centre,

Datta Meghe Institute of Medical Science,

Salod $(\mathrm{H})$, Wardha. India.

Email Id: gajananchatuphale@gmail.com
Amrita (nectar) after logical administration (5). Poison, if taken in the prescribed way, is an increaser of vitality and curer and preventer of diseases and senility. It is an increaser of the properties, good or evil, of a thing which is taken with it. It pacifies the three Doshas (basic elements of the body-Vata, Pitta, Kapha), is nutritious and increases semen(6). In one of the classical text books of Rasashastra, an action of Vatsanabha is explained as cardiac tonic and imparts strength. Vatsanabha is indicated in Fever, Ear ache, Skin diseases etc. (7). It is used as an ingredient in preparations of many formulations such as Mrityunjaya rasa, Hinguleshwara rasa, Anandabhairwa rasa (these are names of various formulations) (8). Aconite species contain diterpene (C20) and norditerpene (C19) alkaloids, the Nitrogen molecule of which is usually ethylated or methylated to make them alkamines. C20 diterpenes are relatively low in toxicity, but the esterified, nor diterpene bases have high toxicity. If the ester functions are hydrolysed, toxicity is reduced to that of ordinary diterpenes (9). Chief active principle of Vatsanabha root is an alkaloid named Aconitine. Other alkaloids like pseudo-aconitine, aconine are derived from aconitine (10). Aconitine $\left(\mathrm{C}_{34} \mathrm{~N}_{49} \mathrm{NO}_{22}\right)$ and related alkaloids are highly toxic to cardiovascular \& nervous system. The cardiotoxic and neurotoxic effects 
of Aconitine and related alkaloids are found to be due to their actions on the voltage sensitive sodium channels of the cell membranes of excitable tissues like myocardium, nerves \& muscles (11). The root is usually processed by drying, soaking, or boiling, which significantly reduces its toxicity. Herbal decoctions of aconite are generally prepared by soaking the roots in water or saturated lime water and then boiling. This causes hydrolysis of aconite alkaloids to less toxic benzylaconine and aconine derivatives. Aconite is also used in Indian folk remedies. It is also used as an antipyretic in Ayurvedic medicine, after "detoxification" (12). In Ayurveda; different methods are in practice for the specific Shodhan procedures of Vatsanabha. Therefore, in the present study, the effect of two different shodhan procedures mentioned in the ancient Ayurveda scriptures on Aconitine content i.e. HPLC Quantification of 'Vatsanabha' (Aconitum ferox Wall ex Seringe.) was compared (i.e. with cow's milk and cow's urine).

\section{Materials and Methods}

\section{Collection and selection of drug}

One kilogram of fully matured Vatsanabha (Aconitum ferox Wall ex Seringe.) roots were collected from the local market of Uttarakhand in India and were botanically authenticated by pharmacognosists and sample specimens were kept for future reference. Cow's urine (Gomutra) and Cow's milk (Godugdha) were collected from the local cow shed in the morning and were used for shodhan procedures of the root.

\section{Equipment for Shodhan}

Stainless steel plates circular shapes 2 in number; stainless steel vessel having capacity of 1.5 lit used as Dolayantra (an instrument used to purify various herbs/drugs by boiling), stainless steel rod (35 $\mathrm{cm}$.), cotton thread $30 \mathrm{~cm}$. in length, measuring mug (capacity of $1 \mathrm{~L}$ ), muslin cloth $(45 \mathrm{~cm} \times 45 \mathrm{~cm})$, stainless steel spatula (length $30 \mathrm{~cm}$ ), digital weighing machine, pyrometer, LPG stove, LPG cylinder, Clay pot of 1 litre capacity.

\section{Shodhan Procedures}

Each Shodhan Procedure was carried out in different batches by using two different media (cow's milk and cow's urine) individually.

\section{Shodhan Procedure of Vatsanabha using cow's urine as a media (13) \\ $100 \mathrm{gm}$. of clean and dried roots of Vatsanabha were made into pea sized pieces and were kept in a clay pot having one litre of cow's urine in it for three consecutive days. The pot was kept on the terrace having plenty of sunlight in the month of April. Each day in the morning cow's urine was replaced with the fresh one. On the fourth day, the roots were washed}

with water; the outer cortical layers were peeled off and the product was again washed with warm water. The pieces were dried in sunlight and kept in an air tight glass container and the final product was labelled as Shodhit Vatsanabh (purified Vatsanabha in cow urine).

\section{Shodhan Procedure of Vatsanabha using cow's milk as a media (14)}

$100 \mathrm{gm}$ of clean and dried roots of Vatsanabha were made into pea sized pieces. These pieces were tied in a muslin cloth into a poultice which was suspended in the centre of a steel pot with the help of a steel rod (Dolayantra). Cow's milk was poured in the vessel to completely immerse the poultice. It was then heated on LPG stove for three hours at $100^{\circ} \mathrm{C}$. Level of milk was maintained above poultice level by repeatedly adding boiled hot milk whenever required. Later, the pieces of Vatsanabha were taken out and washed with hot water. The outer cortical layers of the roots were peeled off. After proper drying in sunlight the Vatsanabha pieces were then kept in an air tight glass container as Shodhit Vatsanabh (purified Vatsanabha in cow milk).

\section{Preparation of samples}

\section{Preparation of Standard Solutions (S)}

Accurately weighed $5.0 \mathrm{mg}$ of Standard Aconitine was taken and $2.5 \mathrm{~mL}$ of Methanol HPLC Grade was added to dissolve it. Sonicated for 5 minutes. Filtered it using 0.22 microns syringe and used it for HPLC analysis.

\section{Preparation of Sample Solutions (T)}

All three samples- Ashuddha Vatsanabha (raw non purified Vatsanabha roots), Shodhit Vatsanabha roots (purified in cow urine) \& Shodhit Vatsanabha roots (purified in cow milk) were powdered separately with mechanical grinder and passed though mesh no. 60 .

Preparation of sample solutions of-

$>$ Ashuddha Vatsanabha (raw non purified Vatsanabha roots)

$>$ Shodhit Vatsanabha roots (purified in cow urine)

$>$ Shodhit Vatsanabha (purified in cow milk) were done by following procedure.

Accurately weighed $5.0 \mathrm{gm}$. of sample was added in a $250 \mathrm{ml}$ Iodine flask. $50 \mathrm{ml}$ Methanol was added to it and refluxed for 2 hours. Filtered it in an evaporating dish and concentrated up to $5 \mathrm{ml}$. To this 20 $\mathrm{mL}$ sulphuric acid solution $10 \%$ was added, after proper shaking filtered it. It was made alkaline with strong ammonia solution. This solution was extracted with chloroform $10 \mathrm{~mL}$ for 3 times. Collected all chloroform layers and evaporated it to dryness. Dissolved this in Methanol and volume up to $2 \mathrm{ml}$ was made \& used it for HPLC analysis. 
Chromatographic Conditions

HPLC conditions were as below mentioned-

\begin{tabular}{|l|l|}
\hline HPLC System & Shimadzu UFLC Modular \\
\hline $\begin{array}{l}\text { Stationary Phase } \\
\text { Column } \\
\text { Temperature }\end{array}$ & $\mathrm{C} 18$ \\
\hline $\begin{array}{l}\text { Filtering System } \\
40^{\circ} \mathrm{C}\end{array}$ & $0.22 \mu$ syringe filter \\
\hline $\begin{array}{l}\text { Run time } \\
\text { Sample Application } \\
\text { Volume }\end{array}$ & $60 \mathrm{~min}$ \\
\hline Mobile Phase (MP) & $\begin{array}{l}20 \mu \mathrm{L} \\
\text { Petrahydrofuran }\end{array}$ \\
\hline Flow Rate & $1.0 \mathrm{~mL} / \mathrm{min}$ \\
\hline Wavelength & $238 \mathrm{~nm}$ \\
\hline Mode of Separation & Gradient \\
\hline
\end{tabular}

\section{Observations}

Following four HPLC chromatograms were observed including first for standard Aconitine.

Figure 1: HPLC chromatogram of Standard Aconitine

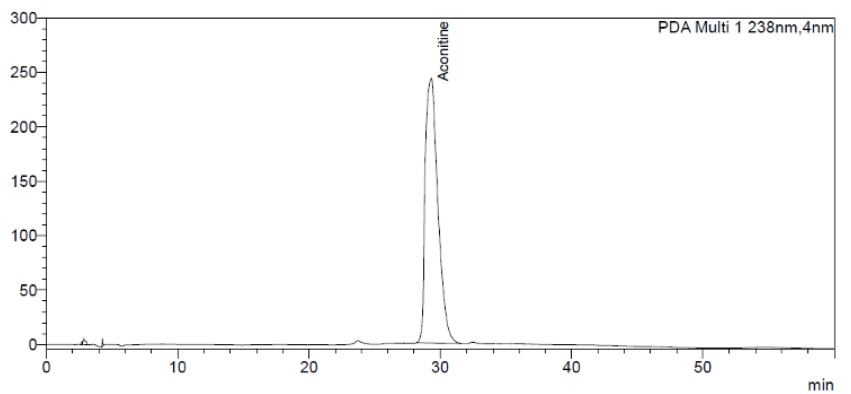

Figure 2: HPLC chromatogram of Ashuddha Vatsanabha (raw non purified Vatsanabha roots)

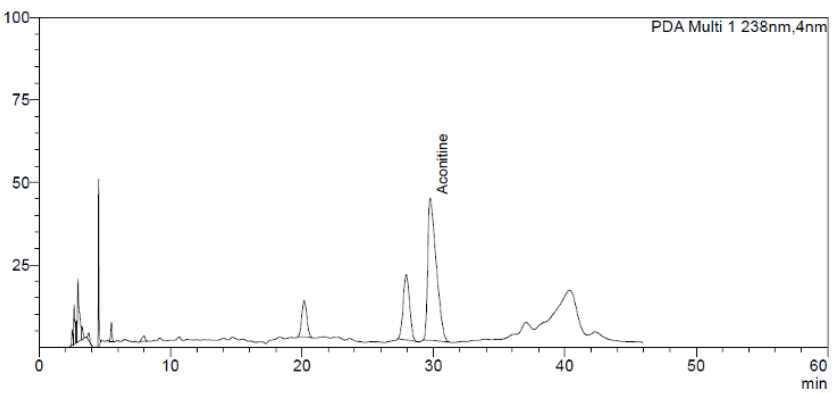

Figure 3: HPLC chromatogram of Shodhit Vatsanabha (purified in cow urine)

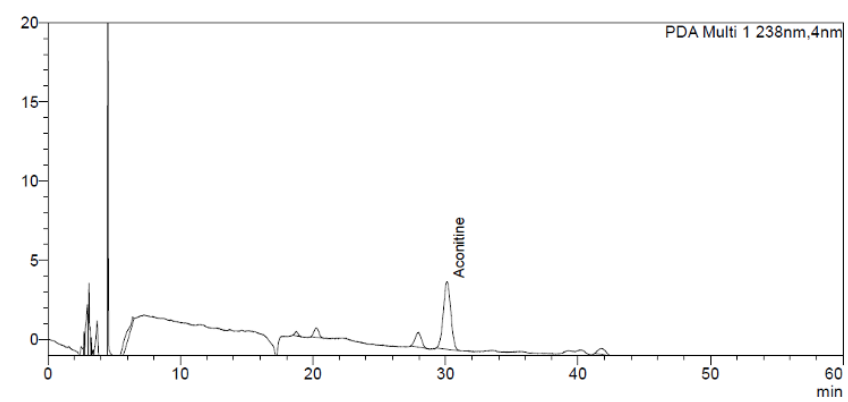

Figure 4: HPLC chromatogram of Shodhit Vatsanabha (purified in cow milk)

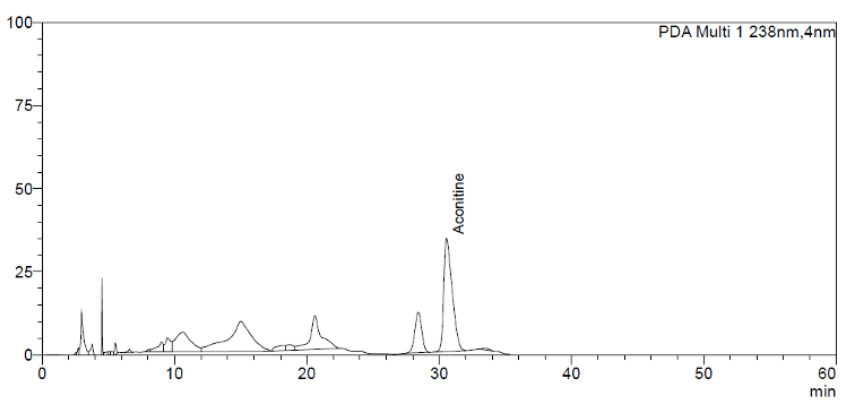

\section{Results}

Table 1

\begin{tabular}{|l|c|c|c|c|}
\hline \multicolumn{1}{|c|}{ Sample } & Aconitine Std. & $\begin{array}{c}\text { Ashuddha Vatsanabha } \\
\text { (raw non purified } \\
\text { Vatsanabha roots)- }\end{array}$ & $\begin{array}{c}\text { Shodhit } \\
\text { Vatsanabha (purified } \\
\text { in cow urine) }\end{array}$ & $\begin{array}{c}\text { Shodhit } \\
\text { Vatsanabha (purified in } \\
\text { cow milk) }\end{array}$ \\
\hline Weight in mg & $2.5 \mathrm{mg}$ & $902 \mathrm{mg}$ & $986 \mathrm{mg}$ & $949 \mathrm{mg}$ \\
\hline Rt & 30.1 & 30.1 & 30.1 & 30.1 \\
\hline Area Under & 16248504 & 1925838 & 166645 & 1500890 \\
Curve & --- & 0.0267 & 0.00205 & 0.0192 \\
\hline Assay (\%) & & &
\end{tabular}

\section{Discussion}

Vatsanabha is one of the most dependable herbs of Ayurvedic formulary which is used in cold and febrile conditions. The formulations containing Vatsanabha are included under the list of essential Ayurvedic medicines for Ayurvedic dispensaries run under centrally sponsored schemes of Govt. of India. This enlistment further endorses to its importance. One of the commonest examples are Tribhuvan Kirti Rasa and Sanjeevani Vati(15). Vatsanabha is cautioned before its internal use throughout the Ayurvedic literatures. This is advised only to be used with caution, with proper shodhan procedure (purification or detoxication) and in right conditions and to the right patients (16). Detoxifying capacity of these shodhan procedures employed for the purification of Aconite are studied and has claimed for a superiority of purified Aconite on its crude counterpart when used internally for medicinal purpose (17). These studies however do not explain for the cause of using various ingredients in purification and also do not explain for a reason of 
superiority between any one of the mentioned methods. Breaking of Vatsanabha roots into small pieces increases the penetrability of any liquid where it is dipped. Cow urine being acidic in nature, may help in reducing the effect of toxic alkaloids to a therapeutic minimum. There is possibility that these toxic ingredients may be dissolved and ooze out in solution for which a urine solution is advised to be changed every morning. Keeping the dipped drug in sun or boiling may help in dissolution of water-soluble or fat soluble toxic substances into the resulting solution as far as cow urine or cow milk is concerned. This explanation however is only a hypothesis unless validated scientifically. This HPLC quantification study specifies that there is presence of one common component Aconitine in all the three samples as peak was seen at Rt 30.1 in all three samples. It means that none of the Shodhan procedure completely denature the Aconitine \& Aconitine is also responsible for pharmaceutical or therapeutic action of Vatsanabha roots. Both the Shodhan procedures have significant impact by reducing Aconitine content of the samples which can be analysed by comparing AUC \& Assay. We have tried to answer which method will be better to follow in future as far as Aconitine is concerned.

\section{Conclusion}

From this study, it is concluded that both the Shodhan procedures reduces the Aconitine content of Vatsanabha Mula as the area under the curve \& assay of the sample in HPLC is reduced. However area under the curve was reduced from 1925838 to $166645 \& 1500890$ $\&$ assay (\%) was reduced from 0.0267 to $0.00205 \&$ 0.0192 in Shodhit Vatsanabha (purified in cow urine) and Shodhit Vatsanabha (purified in cow milk) samples respectively indicating denaturation of some component after Shodhan. From this study it may be concluded that for Shodhan procedure of Vatsanabha Mula, cow's urine (Gomutra) is a better extraction media than cow's milk (Godugdha) as far as toxic alkaloid Aconitine is concerned.

\section{References}

1. Kaviraj Nrupendranathsen Gupta, Kaviraj Balaichandrasen Gupta, Sushrutha Samhitha Part 2 of Acharya Sushruta Kalpsthan chapter 2/11, $1^{\text {st }}$ edition, Kolkata, C.K.Son \& Company limited Kolkata, 1938' 127-128P.

2. Shri Bapalal G. Vaidya, Nighantu Adarsha-Vol-1, 3rd edition, Varanasi, Chaukhambha Bharati Academy, 2002,4-13P.
3. Pandit Kashinath Shastree, Rasatarangini, Sadanand Sharma, Chapter 24, 11th edition, Reprint, Delhi, Motilal Banarasi Das, 2004, 648P.

4. Siddhinandan Mishra, Ayurvediya Rasashastra, Reprint Edition, Varanasi, Chaukhambha Orientalia, 2014, 591P.

5. Kaviraj Shri Ambikadatta Shastri, Shri Vagbhatacharya, Rasaratnasamuchchya Chapter-29/21, Edited with The Suratnojjvala Hindi Commentary and Notes, Introduction, Indices, Appendices etc. by Varanasi, Chaukhambha Sanskrit Series Office, 1976, 586P.

6. Kaviraj Bhudeb Mookerji; Rasajalanidhi or Ocean of Indian Chemistry \& Alchemy; Volume 3; Chapter 7; Delhi; Parimal publications, 1990, 313P.

7. Pandit Kashinath Shastree, Rasatarangini, Sadanand Sharma, Chapter 24, 11th edition, Reprint, Delhi, Motilal Banarasi Das, 2004, 653P.

8. Pandit Kashinath Shastree, Rasatarangini, Sadanand Sharma, Chapter 24, 11th edition, Reprint, Delhi, Motilal Banarasi Das, 2004, 661-675P.

9. Pillay V V, Modern Medical Toxicology, Forwarded by Prem Nair; 4th Edition Reprint, New Delhi, Jaypee Brothers Medical Publishers (P) Ltd, 2013, 341P.

10. Apurba Nandy, Principles of forensic medicine including toxicology; $2^{\text {nd }}$ edition, Reprint, Delhi, New Central Book Agency (P) Ltd, 2010, 895P.

11. Justice K Kannan \& Dr. K Mathiharan, MODI A textbook of Medical Jurisprudence \& Toxicolgy; Jaisingh P. Modi; $24^{\text {th }}$ edition $3^{\text {rd }}$ reprint; Gurgaion; Lexix Nexis Publication; 2013, 258P.

12. Pillay V V, Modern Medical Toxicology, Forwarded by Prem Nair; 4th Edition Reprint, New Delhi, Jaypee Brothers Medical Publishers (P) Ltd, 2013, $341 \mathrm{P}$.

13. Pandit Kashinath Shastree, Rasatarangini, Sadanand Sharma, Chapter 24/19-22, 11th edition, Reprint, Delhi, Motilal Banarasi Das, 2004, 651-652P.

14. Pandit Kashinath Shastree, Rasatarangini, Sadanand Sharma, Chapter 24/23-24, 11th edition, Reprint, Delhi, Motilal Banarasi Das, 2004, 652P.

15. Ministry of AYUSH, Government of India ; Ayurvedic Standard Treatment Guidelines; 1st edition; New Delhi; 2017.

16. Pandit Kashinath Shastree, Rasatarangini, Sadanand Sharma, Chapter 24, 11th edition, Reprint, Delhi, Motilal Banarasi Das, 2004, 656P.

17. Sanjeev Rastogi, Review of Aconite (Vatsanabh) Uses in Ayurvedic Formulations: Traditional views and their inferences. Spatula D.D. 2011:1:233-44 


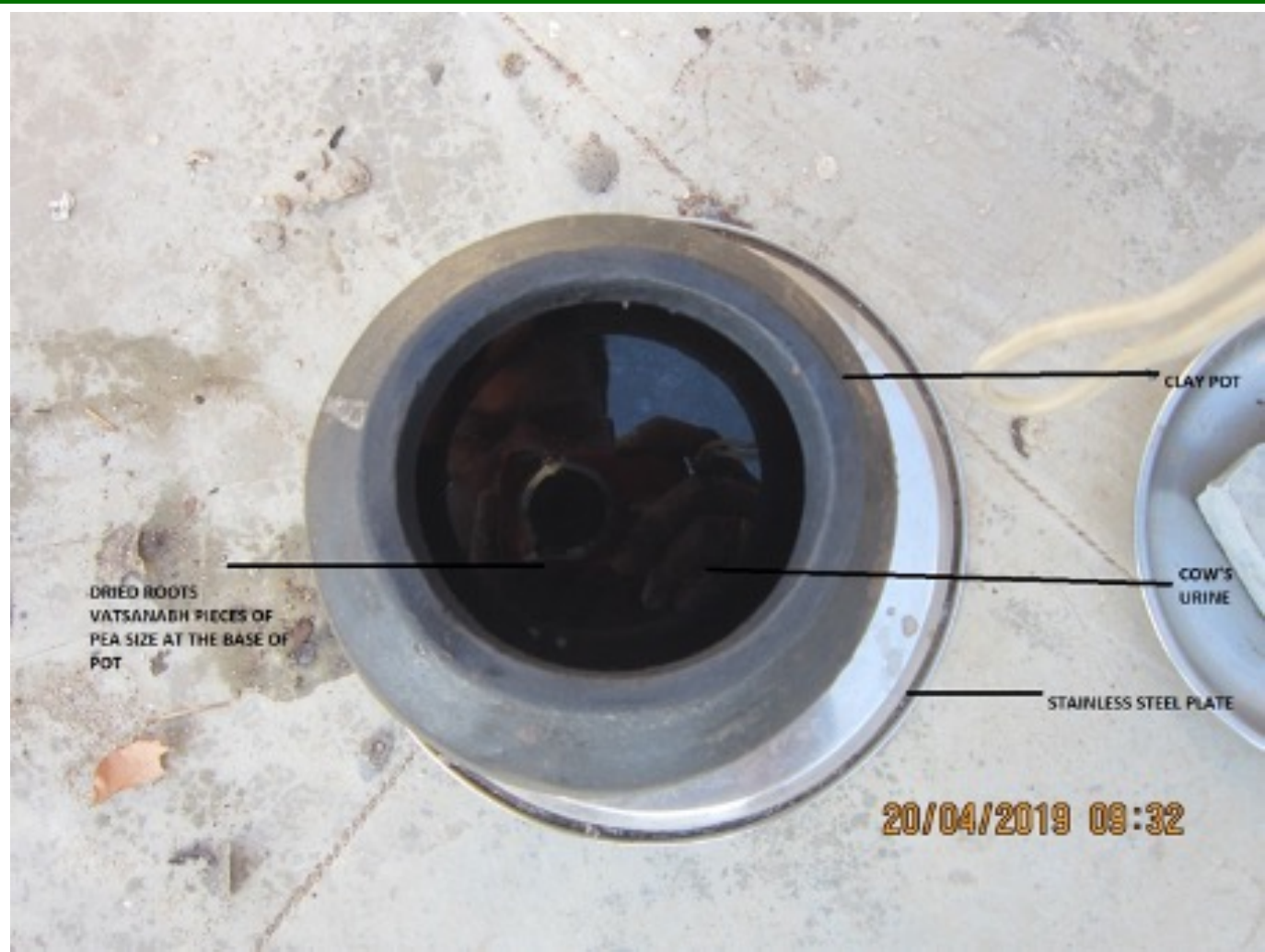

Figure-1- Shodhan Procedure of Vatsanabha using cow's urine as a media

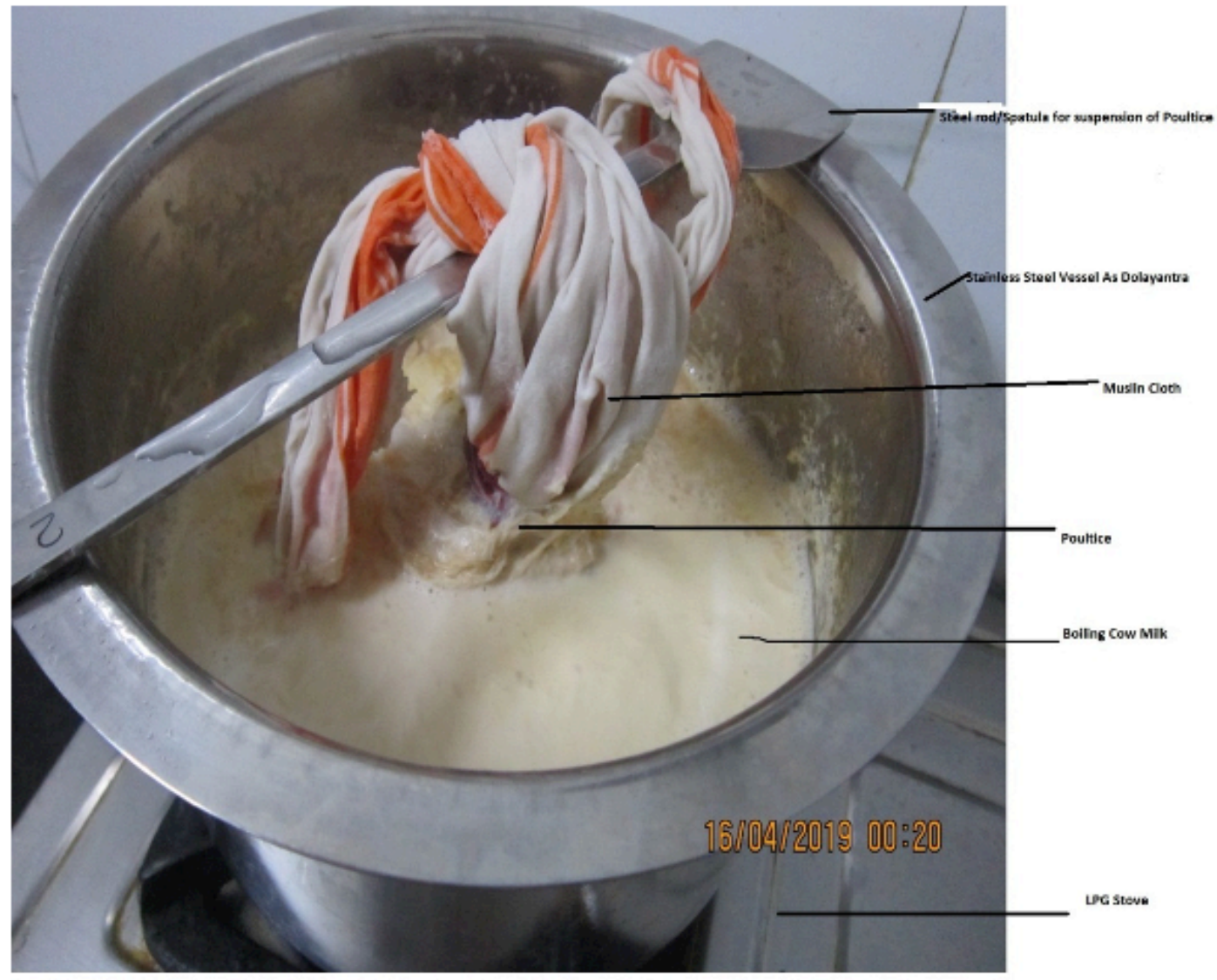

Figure-2- Shodhan Procedure of Vatsanabha using cow's milk as a media

$* * * * *$ 